\title{
MOLECULAR IDENTIFICATION OF AHPND POSITIVE VIBRIO \\ PARAHAEMOLYTICUS CAUSING AN OUTBREAK IN SOUTH-WEST SHRIMP FARMING REGIONS OF BANGLADESH
}

\author{
MD. MOSTAVI ENAN ESHIK, MD. MINHAZUL ABEDIN, NUSRAT JAHAN \\ PUNOM, MST. KHADIZA BEGUM AND MOHAMMAD SHAMSUR RAHMAN* \\ Department of Fisheries, Faculty of Biological Sciences, University of Dhaka, Dhaka \\ 1000, Bangladesh
}

\begin{abstract}
Acute hepatopancreatic necrosis disease (AHPND) of shrimps is a bacterial disease, first appeared in China in 2009 and causes mortality up to $100 \%$ which usually occurs early (within approximately first 35 days) after stocking shrimp fry of black tiger shrimp, Penaeus monodon (Fabricius) and white leg shrimp, Litopenaeus vannamei (Boone). The purpose of this study was to isolate and identify the pathogenic strain of $V$. parahaemolyticus causing AHPND in cultured shrimps (P. monodon) using molecular techniques. After a disease outbreak in April 2017, shrimp samples were collected from three different locations of south-west shrimp farming region of Bangladesh viz. Satkhira, Khulna and Bagerhat districts. In this study, three selective media were used for primary isolation of $V$. parahaemolyticus. Among 28 primary isolates, representative14 isolates were checked for the species-specific detection of $V$. parahaemolyticus using ldh primers and all of them were found to be positive. The isolates were further characterized to check their AHPND positivity using AP3 and AP4 primers. Four isolates showed positive results for both AP3 and AP4 which indicated that the isolates were AHPND positive. This study also report that all AHPND positive strains showed sensitivity to the antibiotics Tetracycline and Nalidixic Acid. The results of this study will help the farmers and policy makers to make plan to protect shrimps from AHPND and thereby sustain the shrimp farming in Bangladesh.
\end{abstract}

Key words: AHPND, EMS outbreak, V. parahaemolyticus, P. monodon, Antibiogram

\section{INTRODUCTION}

Asian shrimp cultivation is an important industry that generates billions of US dollar in export income annually (Flegel 2012). The main cultivated species are Penaeus monodon and Litopenaeus vannamei, with the latter currently dominating the world market (FAO 2013). Acute hepatopancreatic necrosis disease (AHPND) of shrimps is a bacterial disease, first appeared in China in 2009. Since then, AHPND has caused serious drops in shrimp production (up to $20 \%$ worldwide) (Hong et al. 2015). AHPND has caused mortality up to $100 \%$ which usually occurs early (within approximately 35 days)

*Corresponding author: <shamsur@du.ac.bd>. 
after stocking shrimp fry in shrimp ponds; therefore, it was initially referred to as early mortality syndrome (EMS). AHPND affects black tiger shrimp, Penaeus monodon (Fabricius) and white leg shrimp, Litopenaeus vannamei (Boone). The scientists recently found that EMS/AHPND could be initiated by a bacterial agent termed $V$. parahaemolyticus which is transferred through oral and then localizes in the shrimp gastrointestinal tract and create a poison that causes tissue devastation and invalidism of the shrimp digestive system known as the hepatopancreas. Tran et al. (2013) showed that certain strains of $V$. parahaemolyticus belonging to the Harveyi clade are responsible for pathological changes in the hepatopancreas of EMS/AHPND affected animals and are negative for genes encoding the thermostable direct hemolysin (TDH) and TDH-related hemolysin (TRH) that are associated with human pathogenic strains. Vibrio parahaemolyticus is a halophilic Gram-negative bacterium that is a normal inhabitant of marine environments. Most of the $V$. parahaemolyticus isolated from the marine environments are non-pathogenic strains. AHPND-suspected shrimps show gross signs of abnormal HP with significant atrophy and discoloration when compared with the normal shrimps (NACA 2012). The histopathology of AHPND is characterized by massive cell sloughing of HP tubule epithelial cells together with the dysfunction of B, F, R and E cells of HP of affected shrimps (Flegel 2012; Joshi et al. 2014). Detection of $V$. parahaemolyticus isolates is typically based on molecular biological analysis that amplify species-specific gene $l d h$ (lecithin dependent hemolysin) (Taniguchi et al. 1985); and to identify the AHPND positive V. parahaemolyticus strains AP3 (Sirikharin et al. 2014) and AP4 (Dangtip et al. 2015) primers are commonly used.

Recently, in April 2017, there were several reports in the daily newspapers on disease outbreak in shrimp farming regions of Bagerhat and Satkhira (http://www.bdpratidin.com/home/printnews/226104;http://shomoyerkhobor.com/article/11302). Historically in Bangladesh, black tiger shrimp were infected with White spot syndrome virus (WSSV) (Hossain et al. 2014); but according to those reports, this year outbreaks did not seem to be caused by WSSV. Therefore, the aim of this study was to isolate and identify the causative agent of this disease outbreak in shrimp using molecular technique. Moreover antibiotic susceptibility of the isolated $V$. parahaemolyticus was also performed.

\section{MATERIALS AND METHODS}

In the present study, 15 shrimp samples suspected with AHPND were collected from Sadar Upazilla of Satkhira, Rampal of Bagerhat and Rupsa of Khulna Districts; and immediately transported to the Aquatic laboratory of the Department of Fisheries, University of Dhaka. Ice was placed around the bags to lower the temperature $\left(4^{\circ} \mathrm{C}\right)$ during transportation. The shrimp samples were processed and hepatopancreas were collected within 12 hours of collection following aseptic techniques (APHA 1998). 
Sampling of the hepatopancreas was done carefully to avoid contamination with intestinal bacteria. TCBS (Thiosulphate Citrate Bile Salt Sucrose Agar), Hi Chrome Vibrio agar, ChromAgar Vibrio were used for culturing of bacteria. At first, $1 \mathrm{~mL}$ sample and $9 \mathrm{~mL}$ alkaline peptone water (APW) were mixed and $100 \mu \mathrm{l}$ sample was spreaded in TCBS and Hi Chrome Vibrio agar plate. The green colonies from the TCBS agar and the bluish green colonies from the HiChrome Agar Vibrio plates were further purified in TCBS, CHROMagar Vibrio and tryptic soy agar (TSA) supplemented with $2.0 \% \mathrm{NaCl}$. The plates were incubated at $37^{\circ} \mathrm{C}$ for 18 to $24 \mathrm{~h}$, and selected pure isolates were then cryopreserved at $-80^{\circ} \mathrm{C}$ in Luria Bertani (LB) with $30 \%$ glycerol.

After DNA extraction (Rahman et al. 2014), suspected colonies were analyzed for the presence of the species-specific molecular markers of V. parahaemolyticus, i.e. ldh (lecithin dependent hemolysin) as described by Taniguchi et al. (1985). AP3 and AP4 primers were also used to check the species specific pathogenicity as described by Sirikharin et al. (2014) and Dangtip et al. (2015), respectively; these primers target contigs that belong to a plasmid in pathogen. A list of primers to identify AHPND positive $V$. parahaemolyticus is given in Table 1 .

Table 1. List of primers to identify AHPND positive V. parahaemolyticus.

\begin{tabular}{|c|c|c|c|c|}
\hline $\mathrm{SL}$ & $\begin{array}{l}\text { Name of } \\
\text { primer }\end{array}$ & Sequence & Purpose & Ref. \\
\hline 1. & $\begin{array}{l}\text { ldh (lecithin } \\
\text { dependent } \\
\text { hemolysin) }\end{array}$ & $\begin{array}{l}\text { 5`AAAGCGGATTATGCAGAA } \\
\text { GCACTG-3` } \\
\text { 3`-GCTACTTTCTAGCATTTTC } \\
\text { TCTGC-5 }\end{array}$ & $\begin{array}{l}\text { To detect } V \text {. } \\
\text { parahaemolyticus } \\
\text { haemolysin gene }\end{array}$ & $\begin{array}{l}\text { Taniguchi et al. } \\
\text { (1985); Joshi } \text { et } \\
\text { al. (2014) }\end{array}$ \\
\hline 2. & AP3 & $\begin{array}{l}\text { 5'-ATGAGTAACAATATAAAA } \\
\text { CATGAAAC-3' } \\
\text { 5'-GTGGTAATAGATTGTACA } \\
\text { GAA-3' }\end{array}$ & $\begin{array}{l}\text { To detect ToxA \& } \\
\text { ToxB gene }\end{array}$ & $\begin{array}{l}\text { Sirikharin et al. } \\
\text { (2014) }\end{array}$ \\
\hline 3. & $\begin{array}{l}\text { AP4-F1* } \\
\text { AP4-R1 }\end{array}$ & $\begin{array}{l}\text { 5'ATGAGTAACAATATAAA } \\
\text { ACATGAAAC-3` } \\
\text { 3`-ACGATTTCGACGTTCCC } \\
\text { CAA-5 }\end{array}$ & $\begin{array}{l}\text { To detect ToxA and } \\
\text { Tox } \mathrm{B} \text { gene }\end{array}$ & $\begin{array}{l}\text { Dangtip et al. } \\
\text { (2015) }\end{array}$ \\
\hline 4. & $\begin{array}{l}\text { AP4-F2 } \\
\text { AP4-R2 }\end{array}$ & $\begin{array}{l}\text { 5`TTGAGAATACGGGACGTG } \\
\text { GG-3` } \\
\text { 3`-GTTAGTCATGTGAGCACC } \\
\text { TTC-5` }\end{array}$ & $\begin{array}{l}\text { To detect ToxA gene } \\
\text { plus } 12 \text { bp spacer } \\
\text { sequence plus } 9 \mathrm{bp} \\
\text { ToxB gene }\end{array}$ & $\begin{array}{l}\text { Dangtip et al. } \\
\text { (2015) }\end{array}$ \\
\hline
\end{tabular}

*Primer AP4-F1 is identical to primer AP3-F from the AP3 method.

The Kirby-Bauer disc diffusion technique (Bauer et al. 1966) was performed to determine the sensitivity or resistance of pathogenic bacteria to 18 antibacterial compounds (list of 18 antibiotic discs is given in Table 3). Fourteen representative including 4 AHPND positive isolates were inoculated on Muller Hinton Broth (HiMedia, M173-500G, India) and incubated for 24 hours and then the bacterial suspension 
was spread onto the surface of the Muller-Hinton agar using sterile cotton swabs, which were then left to dry for several minutes. The antibiotic discs (Oxoid, USA) were applied on the surface of the agar plate and incubated for 24 hours at $37^{\circ} \mathrm{C}$. Finally, the zone of inhibition was measured to detect susceptibility of the bacteria.

\section{RESULTS AND DISCUSSION}

In this study, three types of selective culture media were used for primary isolation of $V$. parahaemolyticus. Twenty eight $V$. parahaemolyticus isolates were obtained from 15 shrimp samples based on colony morphology (Green Colonies on TCBS plate, Violet Colonies on ChromeAgar Vibrio and Bluish green Colonies on HiChrome Vibrio Agar).

Fourteen representative isolates were used for the species-specific detection of $V$. parahaemolyticus by using $l d h$ primer. Detection for $l d h$ gene fragment showed positive result for all isolates (Fig.1). In one study on AHPND, Joshi et al. (2014) also used ldh for the species-specific detection of $V$. parahaemolyticus and found positive PCR results with all 6 isolates.

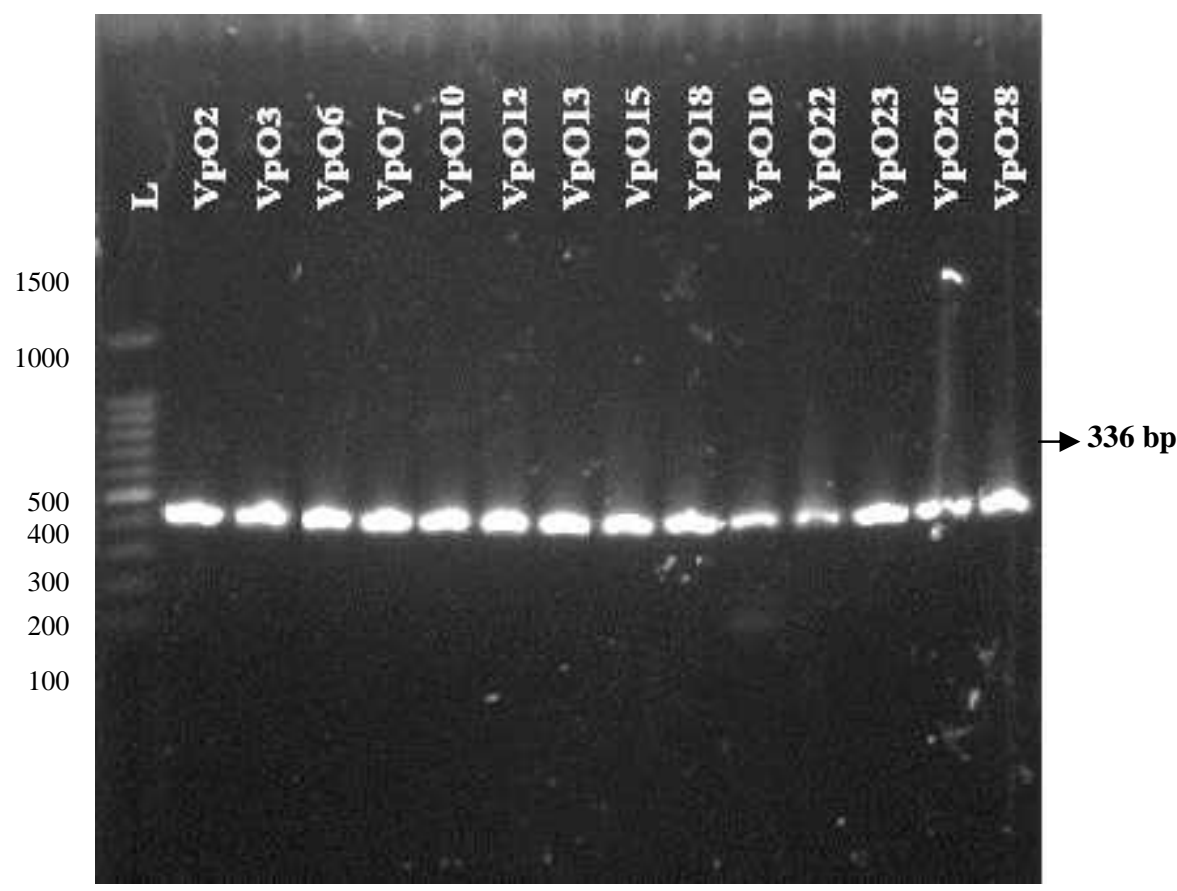

Fig 1. PCR Product profiles of $l d h$ primer generated from 14 representative $V$. parahaemolyticus isolates: $\mathrm{VpO} 2, \mathrm{VpO}, \mathrm{VpO6}, \mathrm{VpO} 7, \mathrm{VpO} 10, \mathrm{VpO} 12, \mathrm{VpO} 13, \mathrm{VpO} 15, \mathrm{VpO} 18, \mathrm{VpO} 19$, $\mathrm{VpO} 22, \mathrm{VpO} 23, \mathrm{VpO} 26$ and $\mathrm{VpO} 28$ and L denotes DNA ladder of $100 \mathrm{bp}$.

The AP3 primers are specific for $V$. parahaemolyticus strains causing AHPND. Fig. 2 illustrates that out of 14 isolates, four isolates ( $\mathrm{VpO} 15, \mathrm{VpO} 18, \mathrm{VpO} 22$ and $\mathrm{VpO} 26)$ were positive for AP3 specific primers. 


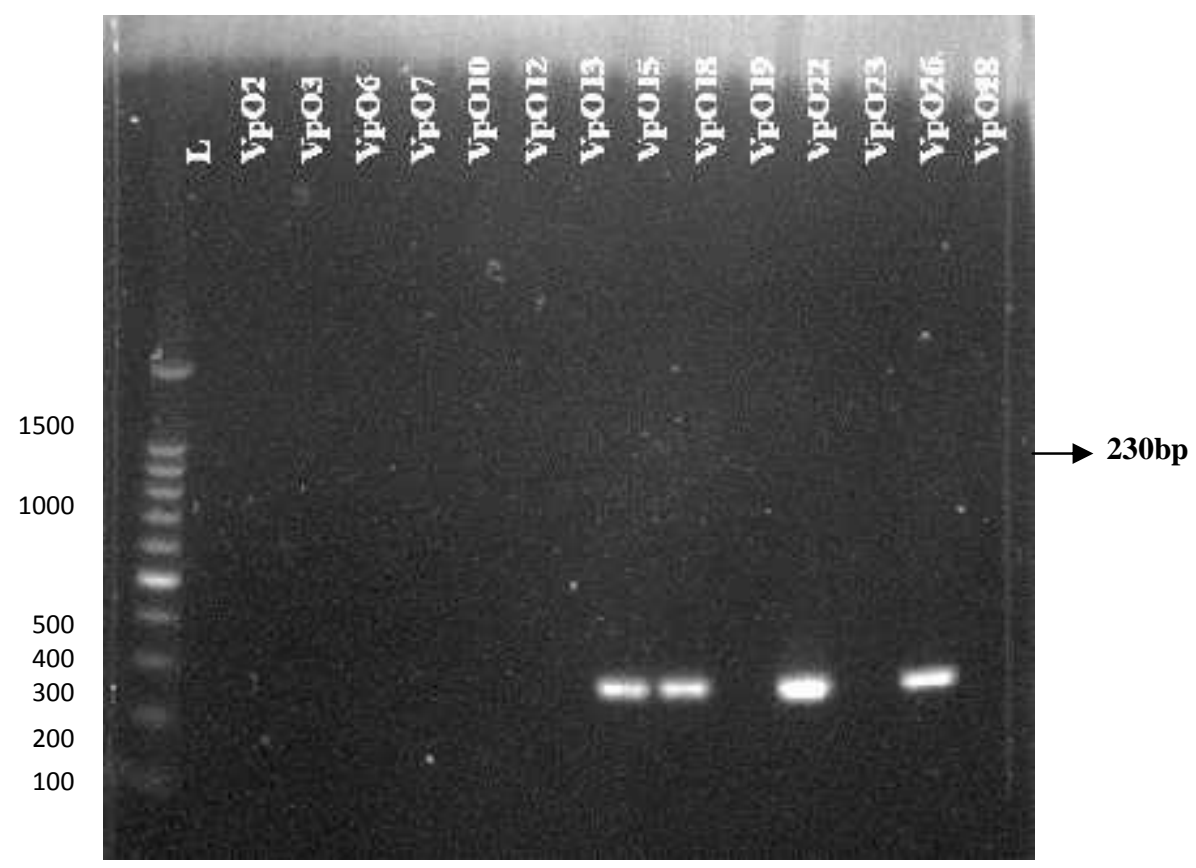

Fig 2. PCR results with the primer AP3 for representative $14 \mathrm{~V}$. parahaemolyticus isolates of shrimp collected from southwest regions of Bangladesh. L denotes DNA ladder of $100 \mathrm{bp}$ Marker.

Kongrueng et al. (2014) used a PCR method targeted to the unique DNA sequences derived from the plasmid (AP2 primers) and the toxin gene (AP3 primers) of $V$. parahaemolyticus that caused AHPND and found a total of 33 of 108 isolates were positive.

In the same study, they found negative results for all clinical and environmental strains of $V$. parahaemolyticus using AP3 primers. Soto-Rodriguez et al. (2015) also used AP3 primer for the detection of pathogenic and nonpathogenic $V$. parahaemolyticus strains. However, AP3 showed a false-positive result in this study (strain M06-04) and produced a predictive positive value of $90 \%$.

The same 14 representative isolates were also subjected to PCR using AHPND specific nested primer pairs AP4. A total of the $4 \mathrm{~V}$. parahaemolyticus isolates (VpO15, VpO18, VpO22 and VpO26) were found positive (Fig. 3; Table 2). Dangtip et al. (2015) worked with AP4 primer and they found that out of 104 isolates, 51 were AHPND positive and 53 were others bacteria including Vibrio. 


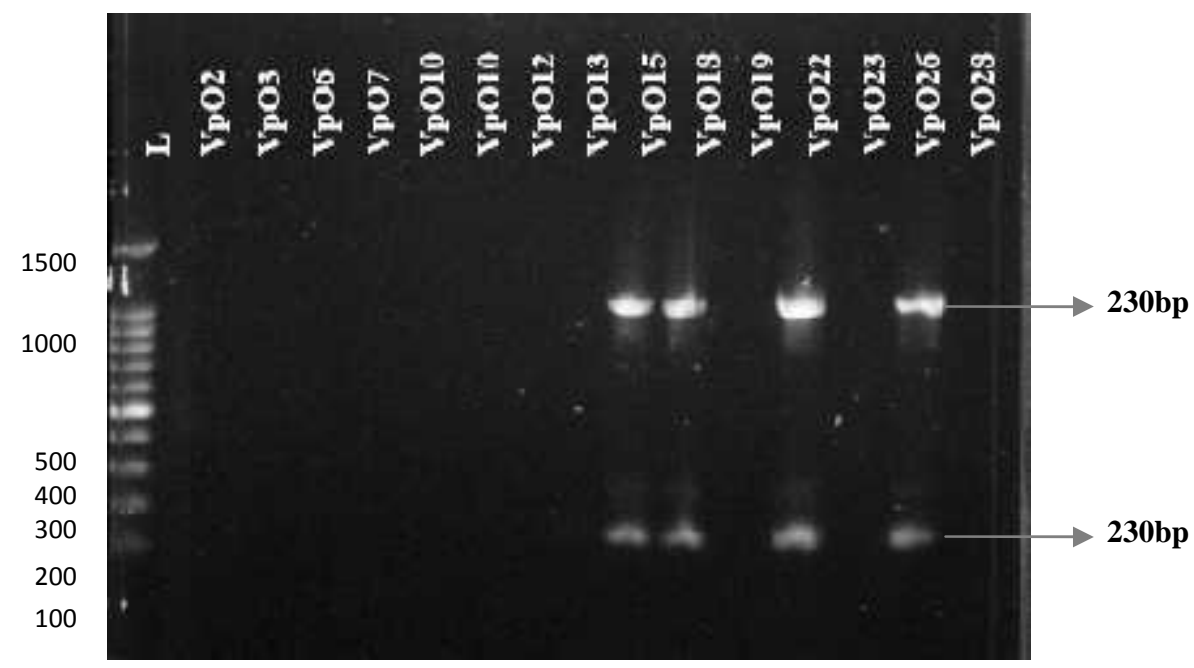

Fig 3. Agarose gel electrophoresis of PCR amplified DNA fragments from representative $V$. parahaemolyticus isolates using AP4 nested PCR. L denotes DNA ladder of 100 bp Marker.

Table 2. Detection of $\mathrm{VP}_{\mathrm{AHPND}}$ isolates using AP3 and AP4 primer based PCR assay.

\begin{tabular}{llll}
\hline Isolate Name & Region & AP3 primer based PCR assay & AP4 primer based PCR Assay \\
\hline VpO2 & Bagerhat & - & - \\
VpO3 & Bagerhat & - & - \\
VpO6 & Bagerhat & - & - \\
VpO7 & Khulna & - & - \\
VpO10 & Khulna & - & - \\
VpO12 & Khulna & - & - \\
VpO13 & Khulna & - & - \\
VpO15 & Bagerhat & + & + \\
VpO18 & Bagerhat & + & + \\
VpO19 & Satkhira & - & - \\
VpO22 & Satkhira & + & + \\
VpO23 & Satkhira & - & - \\
VpO26 & Satkhira & + & + \\
VpO28 & Satkhira & - & - \\
\hline
\end{tabular}

Result of antibiotic susceptibility tests are shown in Tables 3 and 4. Representative $14 \mathrm{~V}$. parahaemolyticus isolates showed $100 \%$ sensitivity to Tetracycline and Nalidixic Acid. On the other hand, most of the isolates were resistant to Amoxycillin $(10 \mu \mathrm{g})$ and Ampicillin $(10 \mu \mathrm{g})$. Chloramphenicol, Ciprofloxacin, Erythromycin were found to have various level of sensitivity for all isolates of $V$. parahaemolyticus. No isolates were resistant to Kanamycin, Gentamycin, Nalidixic acid and Nitrofurantoin. De Melo et al. (2011) reported that in antibiotic susceptibility test five strains (50\%) presented multiple 
antibiotic resistant to ampicillin (90\%) and Amikacin (60\%), while two strains (20\%) displayed intermediate-level of resistance to Amikacin. Xu et al. (2016) reported the antimicrobial resistance patterns of 145 isolates of $V$. parahaemolyticus to 12 antimicrobial agents revealed that most of the isolates resistant to streptomycin, with resistance and intermediate rates of $86.2 \%$ and $11.7 \%$, respectively. In addition, the isolates exhibited relatively high resistance rates, of $49.6 \%, 43.5 \%, 35.9 \%$, and $22.1 \%$, for ampicillin, cefazolin, cephalothin, and kanamycin, respectively.

Table 3. Percentage of antibiotic sensitivity of $14 \mathrm{~V}$. parahaemolyticus isolates against 18 antibiotics

\begin{tabular}{|c|c|c|c|}
\hline \multirow{2}{*}{ Name of Antibiotics } & \multicolumn{3}{|c|}{ Level of sensitivity $(\mathrm{N}=14)$} \\
\hline & $\mathrm{R} \%$ & $\mathrm{I} \%$ & $\mathrm{~S} \%$ \\
\hline Amikacin (AK) $(30 \mu \mathrm{g})$ & $0 \%$ & $7.14 \%$ & $92.86 \%$ \\
\hline Amoxycillin (AML) $(10 \mu \mathrm{g})$ & $78.58 \%$ & $14.28 \%$ & $7.14 \%$ \\
\hline Ampicillin (AMP) $(10 \mu \mathrm{g})$ & $78.58 \%$ & $7.14 \%$ & $14.28 \%$ \\
\hline Azithromycin (AZM) $(15 \mu \mathrm{g})$ & $7.14 \%$ & $21.42 \%$ & $71.44 \%$ \\
\hline Ceftriaxone (CRO) $(30 \mu \mathrm{g})$ & $21.42 \%$ & $21.42 \%$ & $57.16 \%$ \\
\hline Chloramphenicol (C) $(30 \mu \mathrm{g})$ & $14.28 \%$ & $14.28 \%$ & $71.44 \%$ \\
\hline Ciprofloxacin (CIP) $(5 \mu \mathrm{g})$ & $7.14 \%$ & $0 \%$ & $92.86 \%$ \\
\hline Erythromycin $(\mathrm{E})(15 \mu \mathrm{g})$ & $21.42 \%$ & $14.28 \%$ & $64.3 \%$ \\
\hline Gentamycin $(\mathrm{CN})(10 \mu \mathrm{g})$ & $0 \%$ & $14.28 \%$ & $85.72 \%$ \\
\hline 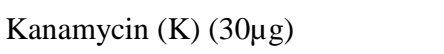 & $0 \%$ & $35.71 \%$ & $64.29 \%$ \\
\hline Nalidixic acid (NA) $(30 \mu \mathrm{g})$ & $0 \%$ & $0 \%$ & $100 \%$ \\
\hline Nitrofurantoin (F) (300unit) & $7.14 \%$ & $14.28 \%$ & $78.58 \%$ \\
\hline 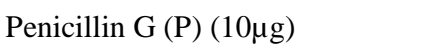 & $57.14 \%$ & $0 \%$ & $42.86 \%$ \\
\hline Polymyxin B (PB) (300unit) & $7.14 \%$ & $0 \%$ & $92.86 \%$ \\
\hline Streptomycin (S) $(10 \mu \mathrm{g})$ & $14.28 \%$ & $35.72 \%$ & $50 \%$ \\
\hline Sulphamethoxazole (SXT) $(25 \mu \mathrm{g})$ & $14.28 \%$ & $0 \%$ & $85.72 \%$ \\
\hline Tetracycline (TE) $(30 \mu \mathrm{g})$ & $0 \%$ & $0 \%$ & $100 \%$ \\
\hline Trimethoprim (W) $(5 \mu \mathrm{g})$ & $28.57 \%$ & $0 \%$ & $71.43 \%$ \\
\hline
\end{tabular}

*R= Resistant, $\mathrm{S}=$ Sensitive, I= Intermediate

The study was conducted to check the presence of AHPND positive $V$. parahaemolyticus during disease outbreak in April 2017 in southern shrimp farming regions of Bangladesh. A total of twenty eight isolates of Vibrio parahaemolyticus were obtained from the shrimp samples collected from disease outbreak areas. Four isolates were confirmed as AHPND positive using AP3 and AP4 nested PCR assay. Further investigations are needed to identify the factors that triggered the disease outbreaks in shrimp farms. Regular monitoring program and necessary policy should be formulated to prevent future disease outbreaks to booster shrimp production in Bangladesh. 
Table 4. Susceptibility of 14 representative $V$. parahaemolyticus including 4 AHPND positive isolates to tested antibiotics.

\begin{tabular}{|c|c|c|c|}
\hline \multirow{2}{*}{$\begin{array}{l}\text { Isolates } \\
\text { name }\end{array}$} & \multicolumn{3}{|c|}{ Antibiotics } \\
\hline & Sensitive & Intermediate & Resistant \\
\hline $\mathrm{VpO} 2$ & AK, C, E, K, NA, CIP, PB, TE, AZM, CN & $\mathrm{F}, \mathrm{S}$ & $\begin{array}{l}\text { AML, AMP, SXT, } \\
\text { P, CRO, W }\end{array}$ \\
\hline $\mathrm{VpO} 3$ & $\begin{array}{l}\text { PB, CN, TE, C, SXT, AZM, E, AMP, } \\
\text { CRO, W, NA, F }\end{array}$ & $\mathrm{K}, \mathrm{AK}$ & S, AML, P, CIP \\
\hline VpO6 & $\begin{array}{l}\text { PB, CN, TE, C, SXT, AZM, E, K, AMP, } \\
\text { P, W, CIP, AK, NA }\end{array}$ & $\mathrm{S}, \mathrm{F}, \mathrm{CRO}$ & AML \\
\hline $\mathrm{VpO} 7$ & $\begin{array}{l}\mathrm{PB}, \mathrm{CN}, \mathrm{TE}, \mathrm{C}, \mathrm{SXT}, \mathrm{E}, \mathrm{F}, \mathrm{CRO}, \mathrm{W}, \mathrm{CIP} \\
\mathrm{AK}, \mathrm{NA}\end{array}$ & $\mathrm{S}, \mathrm{K}$ & $\begin{array}{l}\text { AML, AZM, } \\
\text { AMP, P }\end{array}$ \\
\hline VpO10 & $\begin{array}{l}\text { S, PB, CN, TE, C, SXT, AZM, K, F, P, } \\
\text { CIP, AK, K, NA }\end{array}$ & $\mathrm{E}$ & $\begin{array}{l}\text { AML, AMP, } \\
\text { CRO, W }\end{array}$ \\
\hline VpO12 & S, PB, CN, TE, SXT, F, P, W, CIP, AK, NA & C, AZM, E, K, CRO & AML, AMP \\
\hline VpO13 & $\begin{array}{l}\text { S, PB, CN, TE, C, SXT, AZM, E, F, } \\
\text { CRO, W, CIP, NA, AK }\end{array}$ & & AML, AMP, P \\
\hline VpO15 & $\begin{array}{l}\text { S, PB, CN, TE, AZM, F, CRO, W, CIP, } \\
\text { AK, NA }\end{array}$ & $\mathrm{K}$ & $\begin{array}{l}\text { AML, C, SXT, E, } \\
\text { AMP, P }\end{array}$ \\
\hline VpO18 & $\begin{array}{l}\text { PB, CN, TE, C, SXT, AZM, E, F, CRO, } \\
\text { W, CIP,AK, NA }\end{array}$ & $\mathrm{S}, \mathrm{K}$ & AML, AMP, P \\
\hline VpO19 & $\begin{array}{l}\text { S, PB, AMC, CN, TE, C, SXT, AZM, E, } \\
\text { K, AMP, F, P, CRO, W, CIP, NA, AK }\end{array}$ & & \\
\hline $\mathrm{VpO} 22$ & S, PB, TE, SXT, E, K, F, P, CIP, AK, NA & $\mathrm{CN}, \mathrm{AZM}, \mathrm{CRO}$ & AML, C, W, AMP \\
\hline $\mathrm{VpO} 23$ & $\begin{array}{l}\text { PB, TE, C, SXT, AZM, K, F, P, CIP, AK, } \\
\text { NA }\end{array}$ & $\mathrm{CN}$ & $\begin{array}{l}\text { S, AML, E, AMP, } \\
\text { CRO, W }\end{array}$ \\
\hline $\mathrm{VpO} 26$ & $\begin{array}{l}\text { PB, CN, TE, C, SXT, AZM, K, F, CRO, } \\
\text { W, CIP, NA, AK }\end{array}$ & S, AML & E, AMP, P \\
\hline $\mathrm{VpO} 28$ & $\begin{array}{l}\text { S, CN, TE, SXT, E, CRO, W, CIP, K, } \\
\text { NA, AK }\end{array}$ & AML, C, AZM, AMF & $\mathrm{PB}, \mathrm{F}, \mathrm{P}$ \\
\hline
\end{tabular}

\section{ACKNOWLEDGEMENTS}

We thank Md. Rakibul Islam, SSO and Ariful Islam, SO, Shrimp Research Station (SRS), BFRI, Bagerhat for their assistance during sampling. We also grateful to Sheik Md Selim Al Din, Invent Technologies for his generous support during laboratory work.

\section{REFERENCES}

APHA. 1998. Standard Methods for the Examination of Water and Wastewater. 20th edition, American Public Health Association (APHA), Washington DC. 1325 pp.

Bauer, A.W., W.M.M. Kirby, J.C. Sherris and M. Truck. 1966. Antibiotic susceptibility testing by a standardized single disk method. Am. J. Clin. Pathol. 45: 493-496.

Dangtip, S., R. Sirikharinb, P. Sanguanrutc, S. Thitamadeed, K. Sritunyalucksanab, S. Taengchaiyaphumb, R. Mavichake, P. Proespraiwonge and W.T. Flegel. 2015. AP4 method for two-tube nested PCR detection of AHPND isolates of Vibrio parahaemolyticus. Aquaculture Reports. 2: 158-162. 
De Melo, R.M.L., D. Almeida, E. Hofer, C.M.F. dos Reis, G.N. Diogo Theophilo, M.F. Santos and F.A. Vieira. 2011. Antibiotic resistance of Vibrio parahaemolyticus isolated from pond-reared Litopenaeus vannamei marketed in natal, Brazil. Brazilian J. Microbiol. 42: 1463-1469.

Flegel, T.W. 2012. Historic emergence, impact and current status of shrimp pathogens in Asia. $J$. Invert. Pathol. 110: 166-173.

Food and Agriculture Organization (FAO) of the United Nations. 2013. Report of the FAO/MARD technical workshop on early mortality syndrome (EMS) or acute hepatopancreatic necrosis syndrome (AHPNS) of cultured shrimp (under TCP/VIE/3304). Hanoi, Viet Nam, 25-27 June 2013. FAO Fisheries and Aquaculture Report No. 1053. 54 pp.

Hong, X., L. Lu and D. Xu. 2015. Progress in research on acute hepatopancreatic necrosis disease (AHPND). Aquacult. Int. 24: 1-17.

Hossain, A., S.P. Nandi, M.A. Siddique, S.K. Sanyal, M. Sultana and M.A. Hossain. 2014. Prevalence and distribution of white spot syndrome virus in cultured shrimp. Lett. Appl. Microbiol. 60: 128-134

Joshi, J., J. Srisala, H.V. Truong, B. Nuangsaeng, O. Suthienkul, F.C. Lo, W.T. Flegel, K. Sritunyalucksana and S. Thitmadee. 2014. Variation in Vibrio parahaemolyticus isolates from a single Thai shrimp farm experiencing an outbreak of acute hepatopancreatic necrosis disease (AHPND). Aquaculture. 428-429: 297-302.

Kongrueng, J., M. Yingkajorn, S. Bunpa, N. Sermwittayawong, K. Sngkhamanan and V. Vuddhakul. 2014. Characterization of Vibrio parahaemolyticus causing acute hepatopancreatic necrosis disease in southern Thailand. J. Fish Dis. 38: 957-966.

NACA (Network of Aqua culture Centre s in Asia Pacific). 2012. Disease s of crustaceans-acute hepatopancreatic necrosis syndrome (AHPNS). This disease card was prepared based on the outcome s of the Asia Pacific Emergency Regional Consultation on Early Mortality Syndrome (EMS)/Acute Hepatopancreatic Necrosis Syndrome (AHPNS) held in Bangkok, Thailand, on 9-10 August 2012. 5m Publishing, Sheffield.

Rahman, M.S., M.E. Martino, B. Cardazzo, P. Facco, P. Bordin, R. Mioni, E. Novelli and L. Fasolato. 2014. Vibrio trends in the ecology of the Venice Lagoon. Appl. Environ. Microbiol. 80: $2372-2380$

Sirikharin, R., S. Taengchaiyaphum, K. Sritunyalucksana, S. Thitamadee, T.W. Flegel and R. Mavichak. 2014. A new and improved PCR method for detection of AHPND bacteria. http://www.biotec.or.th/BIOTECen2015/images/stories/News/2014/NewPCR/AP3\%20PCR\% 20detection\%20method\%20announcement.pdf, accessed on 21 July 2017.

Soto-Rodriguez, S.A., B. Gomez-Gill, R. Lozano-olvera, M. Betancourt-Lozano and S.M. MoralesCovarrubias. 2015. Field and Experimental Evidence of Vibrio parahaemolyticus as the Causative Agent of Acute hepatopancreatic Necrosis Disease of Cultured Shrimp (Litopenaeus vannamei) in Northwestern Mexico. Appl. Environ. Micriobiol. 81: 1689-1698.

Taniguchi, H., H. Ohta, M. Ogawa and Y. Mizuguchi. 1985. Cloning and expression in Escherichia coli of Vibrio parahaemolyticus thermostable direct hemolysin and thermolabile hemolysin genes. J. Bacteriol. 162: 510-515.

Tran, L., L. Nunan, M.R. Redman, L.L. Mohney, R.C. Pantoja, K. Kevin Fitzsimmons and V.D. Lightner. 2013. Determination of the infectious nature of the agent of acute hepatopancreatic necrosis syndrome affecting penaeid shrimp. Dis. Aquat. Organ. 105: 45-55.

Xu, X., J. Cheng, Q. Wu, J. Zhang and T. Xie. 2016. Prevalence, characterization, and antibiotic susceptibility of Vibrio parahaemolyticus isolated from retail aquatic products in North China. BMC Microbiol. 16: 32. 